\section{Microbes and men}

Microbes and Men. Producer: Peter Goodchild. BBC2, Wednesday 9.55 pm.

FOR their newest medical/scientific effort, BBC television have homed in on four of the founding fathers of modern medicine and bacteriology, and by means of carefully reconstructed dramatised documentary have tried to tell it as it was. Unfortunately, in the process they have failed to enliven these undoubtedly fascinating characters; Semmelweis, Pasteur, Koch and Ehrlich.

Locations, medical instruments, crucial experiments and the appalling conditions in hospitals at that time are painstakingly reconstructed, and the commentary linking the episodes of dramatic action is lucid, informative and accurate. They have foregone the image of the great scientist and have faithfully documented the petty squabbles, the failures and the obtusenesses as well as the brilliant insights and triumphs.

The fact that in spite of all this the programmes never come alive may be a fault inherent in the presentation itself. Patches of dramatic dialogue are interspersed with the commentary, which although necessary to convey all the hard facts and point the moral in the 55 minutes allowed for each episode, throws an air of unreality over the whole proceedings, especially as the marriage of commentary to picture is sometimes heavy-handed.

The first programme of the series, on the Hungarian doctor Ignatz Semmelweis, screened this week, may, in fact, be the best. Semmelweis was an exceedingly complex character, especially in his failure to follow up his brilliant work on the origins and transmission of puerperal fever, a disease which killed one in three women in childbirth in the 19th century lying-in hospitals. As one character says to Semmelweis' wife in the 'authentic' context of the cosy drawing room, "Science is moving, and I want to make sure he doesn't get left behind". The programmes are in fact littered with this sort of aphorism, usually delivered in ringing tones. The overall effect, for all its undoubted authenticity, is remarkably reminiscent of the great 'lives of the composers' genre of films.

The BBC have seen fit to screen the series relatively late in the evening although the programmes would be eminently suitable for children and would probably be much enjoyed by them. Perhaps the $\mathrm{BBC}$ thought that the blood and gore, especially in the first episode might be off-putting, but children are usually far more resistant than the adult audience for whom it is obviously intended.

A book of the series (Microbes and Men, £2.50) will be available next month.

Eleanor LaWrence

\title{
obituary
}

\section{H. Taylor}

Sir Hugh TAYlor, former graduate school dean and chairman of the chemistry department at Princeton University for 25 years, died at Princeton on April 17, 1974 at the age of 84 .

Born in St. Helens, Lancashire, he received his University training at Liverpool under the tutelage of Sir Frederick Donnan, graduating in 1909 and earning a masters degree in 1910 . In 1912 and 1913 he studied reaction kinetics, the first year at the Nobel Institute at Stockholm with Svante Arrhenius and the second with Max Bodenstein at Hanover Technische Hochschule. In 1914 he was awarded a doctorate at the University of Liverpool. He went from there to Princeton University, where he spent the rest of his tife except for two years during the First World War when he worked in the United Kingdom.

In Princeton, Taylor progressed

\section{Announcements}

\section{Erratum}

In the article "Activation of suppressor $\mathrm{T}$ cells by tumour cells and specific antibody" by R. K. Gershon et al. (Nature, 250, 594; 1974) the end of one sentence and the beginning of the next were inadvertently omitted from the penultimate paragraph. The third and fourth sentences of that paragraph should read 'It is well known that the rapidly through the early professional grades becoming a professor in 1922 and Chairman of the Department of Chemistry by the time he was 36 . He served in this capacity from 1926 to 1951. He also served with distinction as Dean of the Graduate School from 1945 to 1958 . A person as effective as Sir Hugh has no opportunity to retire. After 1958 he continued his dedicated interest in graduate education serving as the first president of the Woodrow Wilson National Fellowship Foundation, the Princeton-based foundation supporting quality in higher education.

Sir Hugh's influence on kinetics has been felt worldwide, especially as applied to catalysis which is a theme running through his 300 scientific papers and his books. The book he wrote with E. K. Rideal Catalysis in Theory and Practice published in 1919 grew out of work by the authors in
Britain during the First World War and was widely used. His contributions to photochemistry, radiochemistry and chemical kinetics were likewise fundamental. During the Second World War, his pioneering efforts in preparing heavy water and diffusion barriers were of great importance to the atomic bomb project.

No picture of Sir Hugh would be complete which left out his generosity, his intense vigour and his decisiveness. $\mathrm{He}$ usually emerged from his office just slightly slower than running. In the seminars which he presided over so superbly, no one could present more quickly and clearly the gist of the problem at hand and place it in proper perspective. With this went a warm enthusiasm and an appreciation of good work by others that made reaction kinetics, and chemistry in general, blossom profitably at Princeton. immunogenicity of antigen is highly dependent on the physical state in which it is administere ${ }^{19}$. Antibody can affect the physical stage of antigen $^{20}$ and in so doing, perhaps, change the $\mathrm{T}$ cell response to it.'

\section{Reports and Publications}

\section{Great Britain}

The Zoological Record. 1970, Vol. 107, Section 6 : Vermes, Part C: Conodonta, Fossil Vermes, Trace Fossils. Compiled by S. Ware. Pp. 22. £3.65. 1970 Vol. 107, Section 13: Insecta. Compiled by the Staff of the Zoological Society of London. Pp. $x+729 . f 12.15$. (London: The Zoological Society of London, 1974.) [107
Philosophical Transactions of the Royal Society of London. B: Biological Sciences. Vol. 267, No. 890 Biomechanics of Pteranodon. By Cherrie D. Bramwel and G. R. Whitfield. Pterodactyls Past and Present. By D. M. S. Watson. D. M. S. Watson's Notes on Pterosaurs. By Cherrie D. Bramwell and G. R Whitfield. Pp. 503-592 + plates 24 and 25. (London:
The Royal Society, 1974.) The Royal Society,

Lawrence Livermore Laboratory in Brief. Pp. 24 Lawrence Livermore Laboratory in Brief. Pp. 24.
(Livermore, California: Lawrence Livermore LaboraSmithsonian Contributions to Zoology. No, 139 Gammaridean Amphipoda of Australia, Part. II By J. Gammaridean Amphipoda of Australia, Part. II By Laurens Banrard. Pp. $\mathrm{v}+148$. \$2.20 No. Fishes of Chile and Peru, with Description of a New Species, Myrodes ornatus, from Chile. By John $S$ (Washington, DC: Smithsonian Institution Press, 1973 and 1974. For sale by US Government Printing Office.) 